DOI: https://doi.org/10.15407/techned2018.06 $\leq \underline{046}$

\title{
THE LAW OF THE ELECTRIC MAGNETIC PROCESSES OF THE SECURITY EXERCISE SYSTEMS OF THE AUTONOMOUS ASYNCHRONIZED GENERATOR ON THE CASE OF THE CASCADE THREE-PHASE THREE-FLEXIBLE VOLTAGE MODULATOR
}

$\quad$ Journal
Publisher
ISSN
Issue
Pages

Tekhnichna elektrodynamika Institute of Electrodynamics National Academy of Science of Ukraine 1607-7970 (print), 2218-1903 (online)

No 6, 2018 (November/December)

$46-49$

\author{
Authors \\ L.I. Mazurenko ${ }^{1 *}$, K.M. Vasyliv ${ }^{2}$ \\ 1 - Institute of Electrodynamics National Academy of Sciences of Ukraine, \\ pr. Peremohy, 56, Kyiv, 03057, Ukraine, \\ e-mail:mlins@ied.org.ua \\ 2 - Lviv Polytechnic National university, \\ S. Bandery, 12, Lviv, 79013, Ukraine \\ * ORCID ID : http://orcid.org/0000-0002-7059-249X
}

\begin{abstract}
The laws of the course of the electromagnetic processes occurring in the contactless excitation system of the asynchronous generator on the basis of a cascade three-phase, three-phase voltage modulator on the possibility of expansion of the biphonal slip range of the generator are established. The method of correction of parameters of the rotors of the machines of the modulator and generator is offered, which allows to stabilize operation of the switch in the range
\end{abstract}


of slip $S=-1 \div+0,4$. References 4 , figures 5 .

Key words: asynchronous generator, voltage modulator, switch, contactless excitation system, slide.

Received: 05.03.2018

Accepted: 29.05 .2018

Published: 23.10 .2018

\section{References}

1. Yanmei Yao. Study of Induction Machines with Rotating Power Electronic Converter. Doctora I Thesis Stockholm

. Sweden, 2016. URL:

https://www.diva-portal.org/smash/get/diva2:1045804/FULLTEXT01.pdf

2. Naveed Ur Rehman Malik. Modelling, Analysis and Control Aspects of a Rotating Power Electronic Brushless Doubly-Fed Induction Generator. Doctoral Thesis in Electrical Machines and Drives Stockholm Sweden, 2015.

URL:

https://pdfs.

semanticscholar.org/79ee/303c7376f34e74357ec593d49c46243204b0.pdf

3. Galynovskyj A.M. Non-contact asynchronous generator with a modulated frequency converter. Trudy I Mezhdunarodnoi (III Vserossiiskoi) konferentsii po Elektromekhanotronike. Sankt-Peterburgskii gosudarstvennyi elektrotekhnicheskii universitet. 1997. Pp. 182-192. (Rus) 4. Vasyliv K.M. Mathematical model of the dynamic processes of an autonomous electroenergetic system based on a noncontact asynchronized generator with a three-phase three-phase cascade modulated exciter. Tekhnichna Elektro-dynamika. 2004. No 5. Pp. 50-55. (Ukr) 
$\underline{\text { PDF }}$ 